\title{
Evaluation of the Activities on the Development of Social Emotional Learning Skills of the Students: Mixed Method Research
}

\author{
DOI: $10.26466 /$ opus.943392 \\ * \\ Serhat Arslan* - Fatma Ferhan Bahçuvanoğlu** \\ * Doç.Dr., Necmettin Erbakan University, Konya/Türkiye \\ E-Mail: \\ serhatarslan@sakarya.edu.tr \\ ORCID: $0000-0003-4422-8421$ \\ ** Uzman, Yıldız Teknik University, İstanbul/Türkiye \\ E- Mail: $\quad \underline{\text { fbahcuvanoglu@gmail.com }}$ \\ ORCID: $\quad \underline{0000-0003-3959-9922}$
}

\begin{abstract}
It is aimed to investigate whether the activities conducted for Primary School 2nd Year Students are related to the social emotional learning skills of children and whether there are differences in terms of social emotional learning according to their gender, and the relationship between pre-test, post-test and follow-up tests applied to students in this study. The study group of the research includes 17 students studying at Private Erenler Güneş Primary School in Sakarya. Research data collected before 25 February 2020. In the research, the 20item Social Emotional Learning Scale (SELS), which was adapted to Turkish by Akin and Arslan (2013), was used. It was found that the pretest results of the study did not differ in the social emotional learning skills of female and male students. According to the findings obtained after the pretest-posttest analysis, the activity process in which students participated in this subject was found to be beneficial. Considering the mean and total ranges of the difference scores, it was observed that the observed difference was in favor of positive ranks, that is, the post-test score, that is, the social emotional learning skills of children measured before the education increased after the activity period. In addition, it was determined that job description skills, peer relations skills, and self-regulation skills also increased significantly. The second aim of the study is the importance of the concept of social emotional learning in a child's upbringing, what dimensions of SELS skills are used, how to participate in the current training program to acquire sdö skills, how teachers evaluate social skills and emotional management skills and who is the target audience of the sd program. The interview technique, one of the qualitative research methods, was used in the research. As a researcher, a semi-structured interview form was created by me. The interview forms were finalized with the help of expert opinions. Primary school 1st and $2 n d$ grade teachers were asked appropriate questions. The data obtained from the interviews were analyzed by descriptive analysis method. The results of the research based on the interviews: 1- Social Emotional Learning, Bringing Individuals in harmony with the Environment and Society and Personality Development are important for the individual to grow up well 2- Achievements for the Responsible Decision Making, Problem Solving, Relationship Skills from the 5 dimensions of the SELS are targeted. 3-It is stated that there is a need to include activities and increase the gains that are associated with Sdö to participate in the current training program. 5- The target audience of SELS is considered to be all students.
\end{abstract}

Keywords: Social Emotional Learning, Teacher Opinions, Mixed Method, Interview. 


\section{Sosyal Duygusal Öğrenme Becerilerinin Gelişimine Yönelik Yapılan Etkinliklerin Değerlendirilmesi: Karma Yöntem Araştırması}

Öz

Bu araştırmada İlkokul 2. Sınıf Öğrencilerine yönelik yapılan etkinliklerin çocukların sosyal duygusal öğrenme becerileri arasındaki ilişki ve sosyal duygusal öğrenme açısından, cinsiyetlerine göre farklllıklar olup olmadığının incelenmesi, öğrencilere yönelik uygulanan ön test, son test ve izleme testlerinin ilişkisinin incelenmesi amaçlanmıştır. Araştırmanın çalışma grubu Sakarya ilinde Özel Erenler Güneş ilkokul 2. Sinıfında öğrenim gören 17 öğrencidir. Araştırmanın verileri 25 şubat 2020'den önce toplanmıştır. Araştırmada Akın ve Arslan (2013) tarafindan Türkçeye uyarlanan 20 maddelik Sosyal Duygusal Öğrenme Ölçeği (SDÖÖ) kullanılmıştır. Araştırma kapsamında yapılan ön test sonuçlarının kız ve erkek öğrencilerin sosyal duygusal öğrenme becerileri konusunda farklllk göstermediği bulunmuştur. Ön test-son test analizinden sonra elde edilen bulgulara göre öğrencilerin bu konuya yönelik katıldıklar etkinlik sürecinin faydalı olduğu saptanmıştır. Ve fark puanlarının sıra ortalaması ve toplamları dikkate alındı̆̆ında gözlenen farkın pozitif stralar yani son test puanı lehinde olduğu yani çocukların eğitim öncesinde ölçümlenen sosyal duygusal öğrenme becerilerinin etkinlik süreci sonrasinda yükseldiği görülmüş̧ür. Buna ek olarak görev tanımlama becerilerinin, akran ilişkileri becerilerinin, öz düzenleme becerilerinin de anlaml derecede yükseldiği saptanmıştır. Araştırmanın ikinci amacı ise sosyal duygusal öğrenme kavramının bir çocuğun yetişmesindeki önemi, sdö becerisine ait hangi boyutların kullanıldığı, sdö becerilerinin kazanılması için mevcut eğitim programına bu becerinin nasıl katılacağı, öğretmenlerin sosyal beceri ve duygusal yönetim becerilerini nasıl değerlendirdiği ve sdö programının hedef kitlesinin kim olduğunun araştırllmasıdır Bu araştırmada nitel araştırma yöntemlerinden biri olan görüş̧me tekniği kullanılmıştır. Araştırmacı olarak tarafımdan yarı yapılandırılmış görüşme formu oluşturulmuştur. Görüşme formlarına uzman görüşleri yardımıyla son şekil verilmiştir. İlkokul 1. Ve 2. Sinıf öğretmenlerine amaca uygun sorular sorulmuştur. Görüşmelerden elde edilen veriler betimsel analiz yöntemiyle çözümlenmiştir. Görüşmelerden yola çıılarak araştırma sonuçları: 1- Sosyal Duygusal Öğrenme, Çevre ve Toplumla Uyumlu Birey Kazandırmak ve Kişilik Gelişimi, Bireyin iyi yetişmesi için önem taşımaktadır 2- SDÖ' nün 5 boyutundan en çok Sorumlu Karar Verme, Problem Çözme, İlişki Becerilerine yönelik kazanımlar hedeflenmektedir. 3- Sdö'nün mevcut eğitim programına katılması için etkinliklere yer verilmesi, ilişkili olduğu kazanımların arttırılması gerek olduğu belirtilmiştir.4- Öğretmenler Sosyal Duygusal Öğrenme becerisinin gelişimini gözlem yaparak değerlendirmektedirler. 5- SDÖ' nün hedef kitlesinin tüm öğrenciler olduğu düşünülmektedir.

Anahtar Kelimeler: Sosyal Duygusal Öğrenme, Öğretmen Görüşleri, Karma Yöntem, Görüşme. 


\section{Introduction}

Many problems are encountered which have been reflected in the life and relationships of the person, his / her academic and business life through rapidly changing, developing, and altered world. Moreover, increasing violence, stress, cigarette-alcohol and drug addiction, adolescent pregnancy, obesity, diseases, unhealthy conflict solutions in our country and all over the world have a significant impact on the lives of children in the future (Kabakçı, 2006). It has been believed that not developing social emotional skills in schools in a planned way is an important factor in the emergence of this situation (Cohen, 1999; Türnüklü, 2004). It is important to grow up as healthy individuals who are tolerant and empathic, who are able to communicate well with the people around and also give the right decision, who improved morally, who manage their own feelings, plan their career, have high self-esteem and have social awareness to avoid such problems. Improving these skills is related to social-emotional learning. The term social-emotional learning was first heard in a conference held in Fetzer Institution in 1994 (Akcaalan 2016; Baron, 2013; Cherniss, Extein, Goleman and Weissberg,2006). In this conference, targets were set to the students in terms of needs of education, psychology, and health. And this process provides occurrence of SEL (Elbertson, Brackett and Weissberg, 2010; Totan 2011). This group has started working with the aim of solving exclusive problems and behavioral problems, imroving protective programmes which enable increasing of academic achievement (Elias,et al., 1997; Baydan 2010). In 1994, cooperation of advancement in social-emotional learning progress (CASEL) is established with the aim of developing social and emotional learning fact and utilizing internationally used scientific materials in effective school-based applications (Akcaalan,2016; Baron, 2013; Graczyk and others, 2000). CASEL, it emphasizes that emotional learning is compulsory and essential starting from pre-school to higher education to obtain high quality (Baydan 2010; Weissberg, Kumpfer ve Seligman, 2003). Casel is a far-reaching movement which is included educators, researchers, educational politicians, and parents as well as students (Elias, et al., 1997). CASEL which host worldwide studies made in the field of SEL has an important position in spreading this notion. SEL was the 
definition of accepting the students' ideas, feelings and behaviours as a whole, and enhancing the skills that make them successful in their life (Totan 2011). "Social and Emotional learning" in the most extensive meaning is seen as a process of understanding and comprehending social and emotional aspects of our life. This process can be explained in three steps. (Türnüklü, 2004). These are: -to read, analyse and understand the data related to social and emotional areas in our life. -to use the acquired data belongs to social and emotional area solving interpersonal problems encountered in social life. -to be a creative learner in social and emotional part of our life (Türnüklü, 2004). Yet CASEL determines the five dimensions related to one another that include cognitive, affective, and behavioural competence in social and emotional learning (Dusenbury and Weissberg 2017). Self-awareness: It is the ability to define one's own emotions, opinions, and the effects on one's behaviour accurately. Self management: It's the ability of arranging one's own feelings, cognition, and behaviours. Social awareness: It is the ability of comprehending the principle of behaviour and perspective-taking and empathizing with people to identify social environment support. Relationship skills: It is the ability of having and maintaining quality relationship with both individuals and groups. Responsible decision making: It is the ability of making constructive choices about personal behaviours, social interactions, and school (Akcaalaan, 2016; CASEL, 2005; Pikul, 2015). Social and Emotional learning (SEL) is the period that social-emotional maturity grows. Kids and teenagers effectively perform necessary information, attidude and skills to understand and manage emotions, set, and reach positive goals, feel, and show empathy for others, contact positively and keep up, make responsible decision via SEL (Domitrovich, Durlak, Staley, and Weissberg 2017). Besides it is known that socialemotional learning make contributions to raising academic performance, providing psychological state to be good, promoting citizenship duty, helping to be preferred employee by the employers, keeping up the lifelong achievement, risks, problematic relationship, interpersonal violance, using force and lessening unhappiness (Brant, 1999; Elias and Butler; 1999 as cited in Aygün, 2017). Social and emotional learning teaches students how to guide successfully in their personal and academic world (O'Brien and Resnick, 2009; as cited in Pikul, 2015). Social emotional 
learning supports character development, the development of character or positive personal property supports healthy, safe school atmosphere. Safe and healthy school atmosphere increases cognitive achievement. To promote cognitive achievement in the growing of students, to form positive character property and safe school atmosphere are the interwoven targets. With the help of social emotional learning, selfawareness, self-management, social awareness, responsible decision making, and relationship management skills supports this interwoven connection (Elias et.al., 1997; Ellison, 2001; Zins et al., 2004). Self awarenes is the ability of defining the effects on one's own feelings, ideas, thoughts, and behaviours accurately. Self-management is the ability of arranging one's feelings, cognition, and behaviours. Social awareness is the ability of comprehending the principle of behaviour and perspective-taking and empathizing with people to identify social evironment support. Relationship skills is the ability of having and maintaining quality realationship with both individuals and groups. Responsible decision making: It is the ability of making constructive choices about personal behaviours, social interactions, and school (Akcaalan, 2016). It is seen that most of the students start primary school without acquiring such skills as self-expression, emotion-management, anger management, listening, sharing and cooperation however, it is known that social emotional learning skills have been aquired since the preschool period (Türnüklü, 2004). It is thaught that the efforts made on social emotional learning as in the other stages of formal education as well as in the period of primary school that takes place within basic education (Aygün, 2017). In this research it is aimed to answer the questions how students' social emotional learning is related to the activities intended for primary school students and in terms of these two structures gender, academic achievement, and whether there is difference or not about classroom level variables. Moreover, there are evaluations about the importance of class teacher and social emotional learning, how to attend the education programme, who the target group of social emotional learning is. The main purpose of this study is to find out how the activities that are made for students' social emotional skills effect social emotional skills development in an observation group which the primary school 2 nd grade students took place. And also, the importance of social emotional learning, 
the SELS skills of which are used as an aquisition, the target group of SELS and how learning outcomes of sdö are evaluated is stated with the help of qualitative research.

\section{Method}

\section{Research Model}

It is aimed to reveal the perspectives on 1st and 2nd grade teachers working at private and government schools, students social emotional learning skills in the research. Another important purpose of this research is to be able to analyse whether there is meaningful improvement on students' social emotional learning skills as a result of the activities made to increase social emotional learning skills or not. Integrated method is used with exploitation of both quantitative and qualitative work to carry out this research. Population consists of 2 nd grade students studying at Erenler Güneş primary school and class teachers working at 1st and 2nd grade in private and government schools in Sakarya district in 2016-2017 academic Year. The study group of the research includes 17 students studying at Private Erenler Güneş Primary School in Sakarya. Research data collected before 25 February 2020.

\section{Data Collection Tool}

Social Emotional Learning Scale (SELS): 'Social Emotional Learning Scales' is used while collecting data in order to indicate the social emotional learning levels developed by Coryn and others (2009) and translated into Turkish and Turkish validity reliability made by Arslan and Akın (2013). Internal consistency relaibility coefficient is found 90, test repeat reliability was found 71 by Arslan and Akın (2013). Scale resembles type five point likert questions between 1-6 task describing, questions between 7-13 peer relation and questions between 14-20 selfsetting. 


\section{Findings}

Table 1. Are the pre-test and post-test results different from each other?

\begin{tabular}{|c|c|c|c|c|c|c|}
\hline & & $\mathbf{N}$ & Mean Rank & $\begin{array}{l}\text { Sequence } \\
\text { Sum }\end{array}$ & $\mathbf{Z}$ & $\mathrm{p}$ \\
\hline Social Emotional Learning - & $\begin{array}{l}\text { Negative } \\
\text { Sequence }\end{array}$ & $2 a$ & 1,75 & 3,50 & $-3,337 b$ &, $001^{* *}$ \\
\hline Social Emotional Learning & $\begin{array}{l}\text { Pozitive } \\
\text { Sequence }\end{array}$ & $14 \mathrm{~b}$ & 9,46 & 132,50 & & \\
\hline Job description - & $\begin{array}{l}\text { Negative } \\
\text { Sequence }\end{array}$ & $1 \mathrm{~d}$ & 4,00 & 4,00 & $-3,191 b$ &, $001^{* *}$ \\
\hline Job description & Pozitive Sequence & $14 \mathrm{e}$ & 8,29 & 116,00 & & \\
\hline Peer-relations- & $\begin{array}{l}\text { Negative } \\
\text { Sequence }\end{array}$ & $1 \mathrm{~g}$ & 9,00 & 9,00 & $-2,906 b$ &, $004^{* *}$ \\
\hline Peer-relations & $\begin{array}{l}\text { Pozitive } \\
\text { Sequence }\end{array}$ & $14 \mathrm{~h}$ & 7,93 & 111,00 & & \\
\hline Self-arrangement & $\begin{array}{l}\text { Negative } \\
\text { Sequence }\end{array}$ & $3 \mathrm{j}$ & 3,67 & 11,00 & $-2,785 b$ &, $005^{* *}$ \\
\hline Self-arrengement & Pozitive Sequence & $12 \mathrm{k}$ & 9,08 & 109,00 & & \\
\hline
\end{tabular}

In Table 1 Wilcoxon marked sequence test results which are done oriented to make comparison the difference between sub-dimension of self arragement and post education points and the students' social emotional learning skills measured during pretest activity period and accordingly job definition, peer relations are summarised. As it can be seen in the table, there is a significant statistical level diference between the social emotional learning skills points that are gained before preeducation (pre-test) and social emotional learning skills points after getting education for two months (post-test). According to this, the activity period that students attended for this subject has been beneficial. When sequence average of variation points and sum are taken into consideration observed difference is on the side of positive sequence that is test points and as a result it is observed that students' social emotional learning skills evaluated before pre-education period decreased after the activity period. There is a significant statistical level diference between job description skills points that are gained before pre-activities (pre-test) and job description skills points after getting (post-test). According to this, the activity period that students attended for this subject has been beneficial. When sequence average of variation points and sum are taken into consideration observed difference is on the side of positive sequence that 
is test points and as a result it is observed that students' job description skills evaluated before pre-activities period dicreased after the activity period.

There is a significant statistical level diference between peer relations skills points that are gained before pre-activities (pre-test) and peer relations skills points after getting education for two months (posttest). $(p<0,05)$ According to this, the activity period that students attended for this subject has been beneficial. When sequence average of variation points and sum are taken into consideration observed difference is on the side of positive sequence that is test points and as a result it is observed that students' peer-relations skills evaluated before pre-activities period dicreased after the activity period. There is a significant statistical level diference between self-arragement skills points that are gained before preactivities (pre-test) and self-arrengement skills points after getting education for two months (post-test). According to this, the activity period that students attended for this subject has been beneficial. When sequence average of variation points and sum are taken into consideration observed difference is on the side of positive sequence that is test points and as a result it is observed that students' self-arragement skills evaluated before pre-education period dicreased after the activity period.

\section{Are pre-test and observation test results of students different from each other?}

Table 2. Pre-test and observation test results of students

\begin{tabular}{|c|c|c|c|c|c|c|}
\hline & & $\mathbf{N}$ & Mean Rank & $\begin{array}{l}\text { Sequence } \\
\text { Sum }\end{array}$ & $\mathrm{Z}$ & $\mathrm{p}$ \\
\hline \multirow[t]{2}{*}{$\begin{array}{l}\text { Social Emotional Learning - } \\
\text { Social Emotional Learning }\end{array}$} & $\begin{array}{l}\text { Negative } \\
\text { Sequence }\end{array}$ & $0 \mathrm{~m}$ & 0,00 & 0,00 & $-3,518 b$ &, $000^{* *}$ \\
\hline & $\begin{array}{l}\text { Pozitive } \\
\text { Sequence }\end{array}$ & $16 n$ & 8,50 & 136,00 & & \\
\hline \multirow[t]{2}{*}{$\begin{array}{l}\text { Job Definition- } \\
\text { Job Definition }\end{array}$} & $\begin{array}{l}\text { Negative } \\
\text { Sequence }\end{array}$ & $0 \mathrm{p}$ & 0,00 & 0,00 & $-3,539 b$ &, $000^{* *}$ \\
\hline & $\begin{array}{l}\text { Pozitive } \\
\text { Sequence }\end{array}$ & $16 \mathrm{q}$ & 8,50 & 136,00 & & \\
\hline \multirow[t]{2}{*}{$\begin{array}{l}\text { Peer Relations - } \\
\text { Peer Relations }\end{array}$} & $\begin{array}{l}\text { Negative } \\
\text { Sequence }\end{array}$ & $2 \mathrm{~s}$ & 3,25 & 6,50 & $-3,184 b$ &, $001^{* *}$ \\
\hline & $\begin{array}{l}\text { Pozitive } \\
\text { Sequence }\end{array}$ & $14 \mathrm{t}$ & 9,25 & 129,50 & & \\
\hline
\end{tabular}




\begin{tabular}{lllllll}
$\begin{array}{l}\text { Self-regulation }- \\
\text { Self-regulation }\end{array}$ & $\begin{array}{l}\text { Negative } \\
\text { Sequence }\end{array}$ & $1 \mathrm{v}$ & 3,00 & 3,00 & $-3,366 \mathrm{~b}$ &, $001^{* *}$ \\
\cline { 2 - 5 } & $\begin{array}{l}\text { Pozitive } \\
\text { Sequence }\end{array}$ & $15 \mathrm{w}$ & 8,87 & 133,00 \\
\hline
\end{tabular}

${ }^{*} p<.05,{ }^{* *} p<.01$ means there is significant difference.

In table 2. Wilcoxon marked sequence test results which are done oriented to make comparison the difference between sub-dimension self arragement and post education points and the students' social emotional learning skills measured during pretest activity period and accordingly job definition, peer relations are summarised. There is a significant statistical level diference between the students' social emotional learning skills points that are gained before pre-education (pre-test) and social emotional learning skills points after 3 months experienced education period (post-test). $(\mathrm{p}<0,05)$. According to this, the activity period that students attended for this subject has been beneficial. When sequence average of variation points and sum are taken into consideration observed difference is on the side of positive sequence that is test points and as a result it is observed that students' social emotional learning skills evaluated before pre-education period is observed at a high level when compared to pre-activity period after the activity period. There is a significant statistical level difference between the pre-education period (pre-test) job definition skills points of students and job definition skills points that they are educated for a year (observation test). $(p<0,05)$. According to this, the activity period that students attended for this subject has been beneficial. When sequence average of variation points and sum are taken into consideration observed difference is on the side of positive sequence that is test points and as a result it is observed that students' job definition skills evaluated before pre-education period increased after the activity period. There is a significant statistical level diference between the students' social peer-relations skills points that are gained before pre-education (pre-test) and peer-relations skills points after 3 months experienced education period (post-test). $(p<0,05)$. According to this, the activity period that students attended for this subject has been beneficial. When sequence average of variation points and sum are taken into consideration observed difference is on the side of positive sequence that is test points and as a result it is observed that 
students' peer-relations skills evaluated before pre-education period increased after the activity period. There is a significant statistical level diference between the students' social self-arrangement skills points that are gained before pre-activities (pre-test) and self-arrangement skills points after 3 months experienced education period (post-test). ( $p<0,05)$. According to this, the activity period that students attended for this subject has been beneficial. When sequence average of variation points and sum are taken into consideration observed difference is on the side of positive sequence that is test points and as a result it is observed that students' self-arrangement skills evaluated before pre-education period increased after the activity period.

\section{Are pre-test and observation test results of students different from each other?}

Table 3. Post-test and observation test results of students

\begin{tabular}{|c|c|c|c|c|c|c|}
\hline & & $\mathbf{N}$ & Mean Rank & Sequence Sum 2 & & $\mathrm{p}$ \\
\hline \multirow[t]{2}{*}{$\begin{array}{l}\text { Social Emotional Learning - } \\
\text { Social Emotional Learning }\end{array}$} & $\begin{array}{l}\text { Negative } \\
\text { Sequence }\end{array}$ & $2 \mathrm{y}$ & 9,00 & 18,00 & $-2,595 b$ &, $009^{* *}$ \\
\hline & $\begin{array}{l}\text { Pozitive } \\
\text { Sequence }\end{array}$ & $14 \mathrm{z}$ & 8,43 & 118,00 & & \\
\hline \multirow[t]{2}{*}{ Job Defining - Job Defining } & $\begin{array}{l}\text { Negative } \\
\text { Sequence }\end{array}$ & $2 \mathrm{ab}$ & 5,00 & 10,00 & $-2,581 b$ &, $010^{* *}$ \\
\hline & $\begin{array}{l}\text { Pozitive } \\
\text { Sequence }\end{array}$ & $11 \mathrm{ac}$ & 7,36 & 81,00 & & \\
\hline \multicolumn{2}{|c|}{ Peer Relations-Peer Relations Negative } & 3ae & 7,00 & 21,00 & $-1,461 b$ & 144 \\
\hline & $\begin{array}{l}\text { Pozitive } \\
\text { Sequence }\end{array}$ & 9 af & 6,33 & 57,00 & & \\
\hline \multirow[t]{2}{*}{$\begin{array}{l}\text { Self Regulation- } \\
\text { Self regulation }\end{array}$} & $\begin{array}{l}\text { Negative } \\
\text { Sequence }\end{array}$ & $3 a h$ & 4,00 & 12,00 & $-2,144 b$ &, $032^{*}$ \\
\hline & $\begin{array}{l}\text { Pozitive } \\
\text { Sequence }\end{array}$ & 9ai & 7,33 & 66,00 & & \\
\hline
\end{tabular}

In table 3. Wilcoxon marked sequence test results which are done oriented to make comparison the difference between sub-dimension self arragement and post education points and the students' social emotional learning skills measured during pretest activity period and accordingly job definition, peer relations are summarised. As it can be seen in the table, there is a statistical significant level diference between the students' social emotional learning skills points that are gained after 2 months of 
education (final-test) and social emotional learning skills points which is experienced after a period of time passed since the last application of observation (observation test) $(\mathrm{p}<0,05)$.According to this, the benefit of activity period which the students attended referring to this subject is permanent. When sequence average of variation points and sum are taken into consideration observed difference is on the side of positive sequence that is test points and as a result it is observed that students evaluated social emotional learning skills during the period after the last application of post education is observed at a high level permanently. There is a statistically significant level difference between the students' job identification skills points after taking education for 2 months (final test) and the job identification skills points which is experienced after a period passed since the last application of Observation (observation test) $(\mathrm{p}<0,05)$. According to this, the benefit of activity period which the students attended referring to this subject is permanent. When sequence average of variation points and sum are taken into consideration observed difference is on the side of positive sequence that is test points and as a result it is observed that students' evaluated job identification skills during the period after the last application of post education is observed at a high level permanently. There is no statistically significant level diference between the students' peer relations skills points that are gained after 2 months of activities (final test) and peer relations skills points which is experienced after a period passed since the last application of observation (observation test) $(\mathrm{p}<0,05)$. According to this, the benefit of activity period which the students attended referring to this subject is permanent.

There is a statistically significant level diference between the students' self-regulation points that are gained after 2 months of activities (final test) and self-regulation skills points which is experienced after a period passed since the last application of observation (observation test) $(p<0,05)$. According to this, the benefit of activity period which the students attended referring to this subject is permanent. When sequence average of variation points and sum are taken into consideration observed difference is on the side of positive sequence that is test points and as a result it is observed that students evaluated self-regulation skills during the period after the last application of post activities is observed at a high level permanently. 


\section{The Term of Social Emotinal Learning Evaluated by The Teachers Directed To The Findings Related To Qualitative Research}

The tables are created and illustrated according to the opinions of teachers related to social emotional learning term in bringing up a child. The opinions of teachers about social emotional learning term are illustrated in Table 4.

Table 4. The opinions of class teachers about social emotional learning term.

\begin{tabular}{|c|c|c|c|}
\hline Theme(Categories) & Codes & $\mathrm{n}$ & $\%$ \\
\hline $\begin{array}{l}\text { The importance of } \\
\text { emotional learning }\end{array}$ & $\begin{array}{l}\text { socialAquiring well adjusted Individual with the environment an } \\
\text { society (T1, T2, T3, T5, T7, T10, T12, T13, T14, T16, T18, T19) } \\
\text { Personality development and provided by well education (T) } \\
\text { T2, T5, T6, T8, T11, T15, T16, T17, T20) } \\
\text { Ability of expressing yourself (T3, T6, T7, T18, T19, } \\
\text { T20) } \\
\text { Imroving the ability of problem solving (T2, T4, T19, T20) }\end{array}$ & $\begin{array}{l}\mathrm{d} 12 \\
6 \\
6\end{array}$ & $\begin{array}{l}30 \\
20\end{array}$ \\
\hline
\end{tabular}

When the table 4 is observed, the teachers' opinions about social emotional learning term is mostly seen bringing up well adjusted individuals at the rate of $60 \%$. There are other opinions in order at the rate of $50 \%$ personality development and individuals provided by well education, $30 \%$ the ability of expressing yourself, $20 \%$ imroving the ability of problem solving. The exact quotations from teachers opinions are presented below:

"Knows oneself, behaves confidently in society." T18

"In this period the attidudes and behaviours that the child have plays an important role in personality development."T1

The opinions of which proportion the class teachers use as an aquisition at the education programmes belongs to social emotional learning skills (self-awareness, self-management, relation skills, socialawareness, responsible decision making and problem solving) are illustrated in Table 5. 
Table 5. the ones that the class teachers use from the items (self-awareness, selfmanagement, relation skills, social-awareness, responsible decision making and problem solving) belonging to social emotional learning skills.

\begin{tabular}{llcc}
$\begin{array}{l}\text { Theme } \\
\text { (Categories) }\end{array}$ & Codes & $\mathbf{n}$ & \% \\
\hline $\begin{array}{l}\text { Sub-dimentions } \\
\text { of social } \\
\text { emotional }\end{array}$ & $\begin{array}{l}\text { Responsible decision making, problem solving } \\
\text { (T2,T3,T4,T5,T6,T9,T10,T12,T13,T15,T16,T17, }\end{array}$ & 15 & 75 \\
learning & T18,T19,T20) & & \\
& Relation skills (T1,T3,T4,T6,T8,T12,T13,T15,T16,T17.T19,T20) & 12 & 60 \\
& Social Awareness (T2,T3,T4,T8,T9,T10,T12,T13,T16,T19,T20) & 11 & 55 \\
& Self-awareness (T1,T3,T4,T5,T7,T8,T12.T13.T16,T19,T20) & 11 & 55 \\
& Self-management (T1,T2,T5,T6,T8,T11,T15.T16.T17,T20) & 10 & 50 \\
& Sub-dimentions(T3,T4,T8,T12,T16,T19) & 6 & 30
\end{tabular}

When Table 5 is observed, responsible decision making and problem solving at the rate of $75 \%$ is seen related to which aspects belonging to social emotional learning term the teachers used. Other opinions in order, $60 \%$ relation skills, $55 \%$ self-awareness, 50\% self-management, and 30\% which all the aspects are used in. The exact quotations from teachers opinions are presented below:

"In our education programme, we practice self-awareness, relation skills, social awareness, responsible decision making and problem solving aspects as an aquisition." T20

"I think the studies intended to self- awareness, self-management and relation skills are very important." T1

The ideas are illustrated below in Table 6 about how social emotional learning term adapted to existing education programme.

Table 6. the ideas of teachers about how social emotional learning term adapted to existing education programme.

\begin{tabular}{llll}
\hline Theme (Categories) & Codes & $\mathbf{n}$ & $\mathbf{\%}$ \\
\hline How to attend & Social Activities (T1, T7, T10, T12, T18,T 20) & 6 & 30 \\
Education & With related aquisitions (T2, T5, T11,T14, T15) & 5 & 25 \\
programme of & Student centered Education (T3, T8, T10, T13,T 17) & 5 & 25 \\
SDÖ & Dramatization (T4, T6, T13, T18) & 4 & 20
\end{tabular}

When Table 6 is observed, it is seen that the ideas of teachers about how social emotional learning term adapted to existing education programme are mostly at the rate of $30 \%$ with the help of social activities. 
Other ideas take place in order $25 \%$ the related aquisitions and student centered education, $20 \%$ dramatization method. The exact quotations from teachers opinions are presented below: "Social activities must be focused on." T1

"Students can attend by determining the related aquisition." T2

\section{Discussion and Conclusions}

In the applied pretest- post test survey report, the effect of social and emotional learning skills of students on the activities arranged for 2 hours throughout 2 months has been evaluated. The qualities of scale that has been used involve social emotional learning skills, job description, peer relations and sub-dimentions of self-arrangement. According to the findings that were gained after the pre-test post test analysis the activity period that students attended referring to this subject was determined to be beneficial. When sequence average of variation points and sum were taken into consideration observed difference is on the side of positive sequence that was test points and as a result it was observed that students' social emotional learning skills evaluated before pre-education period was observed at a high level. Moreover, job description skills, peer relations skills, self arrangement skills were determined to increase at a significant degree. It was evaluated whether the contribution to social emotional learning skills were permanent after 3 months lapse of period from the last test application of self-awareness, self management, responsible decision making, relation skills, and social awareness aquisition activities that 2 nd graders in company with teachers attended. According to the findings that were gained after the last test-observation analysis the skills the students aquired during the activity period refferring this subject was observed to be permanent. In addition, the development of students in duty identification skills and self-arragement skills continues that was the benefit was observed to be permanent. However, the benefits that students gained in peer relation skills hasn't decreased but it's observed that the increase has stopped. There is a statistical significant level diference between the students' peer relations skills points that are gained before education (pre-test) and peer relation skills points which is experienced after 3 months education (post-test). 
According to this, the benefit of activity period which the students attended referring to this subject is permanent. According to findings duty identification skills of students after the activity period, when compared to the pre activity period are observed to be higher. Related to this study, the study that is made on problem solving skills education programme on students' social emotional learning skills by Totan (2011) is observed that the students that received problem solving skills education programme has changed positively their job identification skills at a significant level after the education period. According to findings peer relation skills after the activity period are observed to be high when compared to the pre activity period. Smilarly, in the work that is arranged by Totan (2011) 6th grade students received problem solving skills education programme are observed to have higher peer relations skills after the education period. According to findings self arrangement skills are seen to be higher after the activity period compared to the pre education period. And also, in the work that is arranged by Totan (2011) 6th grade students received problem solving skills education programme are observed to have higher self arrangement skills after the education. So the permanence significant effect of the activity application that is made about peer relation skills is becoming a controversial issue. One of the sub- problems that takes place in the research is the teachers'opinions about social emotional learning term. With this research the questions are replied on the importance of social emotional learning in bringing up children with the help of teachers at private and government schools, which of the social emotional learning skills are used as an aquisition in education programme, how social emotional learning skills can be added to our existing education programme, how the students evaluate social emotional management skills and who the target group of social emotional learning is. According to the results obtained from our research social emotional learning in terms of growing up a child as an individual adaptable to the environment and the society, personality development, well grow up individuals, expressing oneself and solving problem are important. To understand, direct and express one's responsibilities of social emotional aspects means that individual's learning, have a relationship, solving daily problems and adapting to the demands that occurs as a result of growing (Elias,et al., 1997; Strum, 2001). Buchanan and others (2009), according to the result of 
the research that teachers aimed to observe information, perception and applications about social emotional learning most of the teachers believe that social emotional learning is important, schools should play an active role, education, seminar or support from experts about the subject will help the teachers and resulted in existing academic demands reduces the possibility of social emotional learning. In his research observing the activities and information supporting social emotional class atmosphere, Pech (2010) illustrated that teachers must know with the method of using democratic application supporting the students' social emotional lifes has a lot of benefits.It is stated that integrating self awareness, social responsibility, co-operation, problem solving with meaningful methods forms a sympathetic and supportive class. Mostly responsible decision making and problem solving belonging to the aspects of social emotional learning term are seen as an aquisition by the teachers. On the other hand, relation skills, self-awareness, self management are used. Contrary to this, in Aygün 2017 research where the opinions of class teachers about socialemotional learning skills and social-emotional learning programmes in accordance with the first research question; is understood that most of the teachers attended to the research had never heard about social-emotional learning term. When Haney (2013) observed the education programme that contains the social emotional learning skills of a teacher teaching to 3rd graders, self management and responsible decision making skills are observed to be mostly used among the five skills of SELS, other three skills (self awareness, social awareness and relation skills) are used less. These suggestions can be made by evaluating the results of research: Observing the effectiveness of the activities made oriented to social emotional learning skills at different age levels will contribute to supporting the findings gained in this research. The opinions of teachers and information about the importance of social emotional learning and effectiveness in order to be observe the practicality of social emotional learning in our country more reliably reaching a large number of examplication will contribute to the research. There has been time limitation in the research. It is thought that the activities extended over a period of time and continuance would increase students' social emotional learning skills positively. The permanence of the programme was searched three monts 
later. The permanence of programme effect for 6 months period could be examined.

\section{References}

Arslan, S. and Akın, A. (2013). Social emotional learning scale: The study of validity and reliability. Sakarya Üniversitesi Eğitim Fakültesi Dergisi, 25, 23-34.

Aygün, H. E. (2017). Sosyal-duygusal öğrenme programlarinin sosyal-duygusal öğrenme becerilerinin gelişimine, akademik başari ve sinif iklimi algisina etkisi. Yayımlanmamış doktora tezi. Çanakkale Onsekiz Mart Üniversitesi, Eğitim Bilimleri Enstitüsü, Çanakkale.

Akcaalan, M. (2016). Yaşam Boyu öğrenme ile sosyal duygusal öğrenme arasındaki ilişkilerin çeşitli değişkenler açısından incelenmesi. Sakarya Üniversitesi, Eğitim Bilimleri Enstitüsü, Sakarya.

Baron, D. M. (2013). Social and emotional learning: An argument for religious Pluralism. Loyola University, Chicago.

Baydan, Y. (2010). Sosyal-Duygusal Beceri Algisi Ölçeği'nin geliştirilmesi ve sosyalduygusal beceri programinin etkililiği. Hacettepe Üniversitesi, Enstitü, Ankara.

Buchanan, R., Gueldner, B. A., Tran, O. K. and Merrell, K. W. (2009). Social and emotional learning in classrooms: a survey of teachers' knowledge, perceptions, and practices. Journal Of Applied School Psychology, 25(2), 187-203.

Collaborative For Academic Social And Emotional Learning (2005). What is social and emotional learning? Retrieved From Http://Www.Casel.Org/Social And-Emotionallearning/. 20.04.2020.

Cohen, J. (1999). Social and emotional learning past and present a psychoeducational dialogue. In J. Cohen (Ed.), Educating Minds and Hearts Social Emotional Learning and the Passage into Adolescence. p.323, Teachers College Press, New York.

Cherniss, C., Extein, M., Goleman, D. and Weissberg, R. P. (2006). Emotional intelligence: What does the research really indicate? Educational Psychologist, 41(4), 239-245.

Domitrovich, C. E., Durlak, J. A., Staley, K. C. and Weissberg, R. P. (2017). Social-emotional competence: An essential factor for promoting 
positive adjustment and reducing risk in school children. Child development, 88(2), 408-416.

Dusenbury, L. and Weissberg, R. P. (2017). Social emotional learning in elementary school: Preparation for success. The Education Digest, 83(1), 36.

Elias, M., Zins, J., Weissberg, R., Frey, K., Greenberg, M., Haynes, N., Kessler, R., Schwab, S.M. and Shrive, R. T. (1997). Promoting social and emotional learning: Guidelines for educators. Alexandra, VA: ASCD.

Elbertson, N. A., Brackett, M. A. and Weissberg, R. P. (2010). School-based social and emotional learning (SEL) Programming: Current perspectives. A. Hargreaves, M. Fullan, D. Hopkins ve A. Lieberman (Eds.). The second international handbook of educational change. (p.1017-1032). New York: Springer.

Elias, M., Zins, J., Weissberg, R., Frey, K., Greenberg, M., Haynes, N., Kessler, R., Schwab, S.M. and Shrive, R. T. (1997). Promoting social and emotional learning: Guidelines for educators. Alexandra, VA: ASCD.

Graczyk, P. A., Matjasko, J. L., Weissberg, R. P., Greenberg, M. T., Elias, M. J. and Zins, J. E. (2000). The role of the collaborative to advance social and emotional learning (Casel) in supporting the implementation of quality school-based prevention programs. Journal Of Educational and Psychological Consultation, 11(1), 3.

Haney, K. G. (2013). An observational case study of one third grade teacher's taught social and emotional skills curriculum. University Of Oklahoma Norman, Oklahoma.

Kabakçı, Ö.F. (2006). İlköğretim ikinci kademe öğrencilerinin sosyal-duygusal öğrenme becerileri. Hacettepe Üniversitesi, Eğitim Bilimleri Enstitüsü, Ankara.

Pech, S. L. (2010). A case study of a kindergarten teacher: examining practices and beliefs that support the social emotional classroom climate. Ph.D. Dissertation. Kent State University, Kent State University College and Graduate School of Education, Health, and Human Services, Ohio.

Pikul, M. A. (2015). Changes in the social and emotional wellness of students after participation in a mentoring program. Unpublished doctoral dissertation. Concordia University, Faculty of Arts and Science, Montreal.

Strum, J. R. (2001). An action research study of a social-emotional learning program and its effect on the behavior and academic success of fifth grade students. Thesis. University Of California, School of Social Sciences, California. 
Totan, T. (2011). Problem çözme becerileri eğitim programının ilköğretim 6. sinıf öğrencilerinin sosyal-duygusal öğrenme becerileri üzerine etkisi. Doktora Tezi. Dokuz Eylül Üniversitesi, Eğitim Bilimleri Enstitüsü, İzmir.

Türnüklü, A. (2004). Okullarda sosyal ve duygusal öğrenme. Kuram ve Uygulamada Egitim Yönetimi Dergisi, 10(1), 136-152.

Weissberg, R.P., Kumpfer, K.L. and Seligman, M.E.P. (2003). Prevention for children and youth that works. American Psychologist, 58, 425-432.

\section{Citation Information}

Arslan, S. ve Bahçuvanoğlu, F. (2021). Evaluation of the activities on the development of social emotional learning skills of the students: Mixed method research. OPUS- International Journal of Society Studies, 18(44), 7464-7482. DOI: 10.26466/opus.943392. 